Accepted manuscript of:

Susanne Janssen (2001). The empirical study of careers in literature and the arts. In: Dick Schram and Gerard Steen (Eds.) The Psychology and Sociology of Literature. Amsterdam: John Benjamins, pp. 323-357. https://doi.org/10.1075/upal.35.19jan

\title{
The empirical study of careers in literature and the arts
}

Susanne Janssen ${ }^{1}$

\section{Introduction}

In the last few decades, scholars from a variety of disciplines - (art) history, literary studies, sociology, mass communication studies, psychology, and cultural economics - have contributed to our understanding of production and profession in literature and the arts. Their studies cover different periods and societies and address a broad range of topics which, in one way or another, relate to the work and careers of those involved in the production and distribution of culture. As space is limited, this rich line of research will be reviewed only in part in this article.

Primarily, the focus will be on careers in literature and the visual arts, although occasionally attention will also be paid to other (both artistic and non-artistic) occupations, because such comparisons have yielded useful insights in the past.

Secondly, this article focuses on writers and artists; other professionals in the field of art and literature, including publishers, editors, agents, dealers, critics, and reviewers will be discussed mainly in terms of how they affect the work and careers of writers and artists. We have restricted our focus in this way for reasons of brevity, but also because there is a relative absence of systematic, empirical research into such 'para-artistic' occupations and their practitioners, especially for the postwar period.

Thirdly, this contribution will deal with the work of writers and other artists in a thematic fashion, rather than focusing on the gamut of theoretical perspectives and approaches in this area. The following sections shed light on the changing support structures on which writers and artists have depended for their livelihood and to gain other types of recognition for their work (section 2), the various ways in which mediators shape individual works and whole careers (section 3), the characteristics of artistic occupations and their implications (section 4), and the recruitment and career development of artists (section 5). The article concludes with some comments on the state-of-the-art of research on artistic work and careers.

Of course, the above topics and questions were not picked at random. They stem from several theoretical perspectives and research traditions that were developed by empirically oriented sociologists of literature and the arts from the 1970s onwards, including the production-of-culture perspective (Peterson 1994); the empirical study of literature and literary systems theory (Schmidt 1980,1993 and 1998); art world research (Becker 1982; Gilmore 1990); and field theory, also referred to as the institutional analysis of the field of cultural (literary) production (Bourdieu 1993; Van Rees 1983). Although these approaches have different points of departure, employ different concepts and methodologies, and focus on different aspects of the production of art and literature, there are no clear-cut divisions between them. Many individual researchers and studies, with good reason, can be and have been considered to be representative of more than one approach. It lies outside the scope of this article to detail all the similarities and differences among the above perspectives and approaches. ${ }^{2}$ It is most important in this context that

${ }^{1}$ Correspondence to: s.janssen@eshcc.eur.nl.

2 This has been done extensively elsewhere. See, among others, Blau (1988; Zolberg 1990; Andringa 1998). Zolberg (1990) discusses the differences between Becker's 'art world' approach and Bourdieu's 'field' analysis. 
they have illuminated, in one way or another, the thoroughly social nature of artistic production by foregrounding the social processes through which all artists acquire the necessary resources to do their job.

Writers and other artists have to acquire financial resources to support themselves and their families, creative resources to help conceptualize aesthetic expression, material resources to actualize artistic work, distributional resources to establish contacts with the art world and exchange their work, and critical resources to legitimate their work and facilitate further resource acquisition. Becker (1982) illustrates this for a variety of artistic media including literature, the visual arts, and the performing arts. His work depicts artists as 'workers' whose creations, far from being the result of individual effort, are the products of collective action by often nameless collaborators. But the social nature of artistic production not only refers to the way in which a variety of people are actually involved in the production of a work itself. Sociological research has also highlighted underlying processes and conditions; the conditions which made the production possible, and those which determine its subsequent course. It has illuminated how social developments and institutions affect, among other things, who becomes an artist, how they become an artist, how they are then able to practice their art, and how they can ensure that their work is produced, performed, and made available to a public. Furthermore, it has shown that judgments and evaluations of works and schools of art, determining their subsequent place in literary and art history, are not simply individual and 'purely aesthetic' decisions, but socially enabled and socially constructed events.

It should be noted, however, that this could not have been achieved without the work that has been done in various other fields of sociology, especially on stratification, work and occupations, and organizations, as well as in the humanities and other social sciences. For example, (art) historians have provided excellent documentation on the changing nature of artistic occupations, emphasizing the role of patronage, the relation between the artist and the public, and the shift from craft roles to art roles. Psychologist have illuminated the personality traits and skills involved in artistic creativity, while cultural economists have shed light, among other things, on the characteristics of artistic labor markets. Hence, although work done in the (empirical) sociology of literature and the arts serves as the main point of departure, this article will liberally draw on insights and data provided by other disciplines as well.

\section{Support structures for the arts}

Unless they create or perform only for their own pleasure, writers and other artists depend directly or indirectly on the social structures that support their work. No matter how much they claim to be unconcerned about these, they are obliged to gain their favor in order to obtain some compensation for their efforts. ${ }^{3}$ Audiences are only one of several different types of support structures for the arts, and are not always the most important. Support structures may encompass a gamut of mechanisms, processes, institutions, or agencies that reward or penalize artistic work. They enable some artists to earn a livelihood and to gain other types of recognition while denying such material and symbolic rewards to others. The allocation of rewards for artistic work may be monopolized by a single structure or may be realized through a plurality of structures. These structures range from simple, direct relations between artist and patron to complex systems involving mediators, networks, and audiences. Support structures provide avenues for obtaining jobs or commissions and for recognizing talent and innovations; moreover, they spread such new knowledge to broader constituencies, including the publics or audiences for the arts that have become pervasive in modern society. Historically, in Western European society, their concrete

For a comparison of the 'production of culture' perspective and the 'institutional' or 'field' approach, see, for example, Van Rees (1985). Bourdieu et al. (1989) and Dörner and Vogt (1994: Chapter 5) consider the differences between 'field' and 'systems' theory.

${ }^{3}$ Here, following Zolberg (1990), the term 'support structures' is used. Others have coined them 'distribution and reward systems' (Albrecht et al. 1970) or simply 'reward structures' (Crane 1976; Rosengren 1983). 
forms include guilds, (church, royal, municipal, and private) patronage, academies, state bureaucratic administration, and the market.

A large body of research has shown how these structures, in different ways, affect artistic careers as well as the art styles and forms that are produced and disseminated for public consumption. It lies outside the scope of this article to detail the subsequent support structures on which writers and other artists have depended to gain material and symbolic compensation for their work. Individual European countries show important variations both in the degree of control exercised by certain support structures and as regards the exact time frame in which they developed and dominated the allocation of rewards for artistic work. ${ }^{4}$ However, roughly, the scenario was similar for most of Europe: patronage declined and the market grew. ${ }^{5}$ Increasingly, publishers and book sellers took over from literary patrons ${ }^{6}$ as facilitators for the writer, ${ }^{7}$ and the patrons of art, as well the academic system, were displaced by the dealer-critic system in painting. ${ }^{8}$ Everywhere new publics for art and literature changed their very nature.

\section{Implications of the transformation from patronage to market}

As an obvious paradox, as the market began the develop, writers and artists found themselves able to affirm the irreducibility of the work of art to the status of single article of merchandise and, at the same time, the singularity of the intellectual and artistic condition. Bourdieu (1985) argues that the emergence of the work of art as a commodity, and the rise of a distinct category of producers of cultural goods specifically intended for the market, to some extent prepared the ground for a pure theory of art, i.e., the idea of art as art. It did so by dissociating art-as-commodity from art-as-pure-symbolism that was intended for purely symbolic appropriation. The end of the dependence upon patrons and direct commissions, with the development of an anonymous market, increased the liberty of writers and artists. However, as Bourdieu points out, this freedom was only relative, as it entailed their submission to the laws of the market of symbolic goods, that is, to a form of demand which necessarily lags behind the supply of the commodity. Writers and artists could hardly fail to notice this demand though the sales figures and other forms of pressure, explicit or diffuse, exercised by publishers, theater managers, and art dealers. In this line of argument, the 'inventions' of Romanticism - culture as representation of a superior reality and the

\footnotetext{
${ }^{4}$ Although, for example, the academic structures of France were widely imitated in other European countries, they achieved not the same central position as in France. While the Académie Francaise (1634) dominated French literary life for centuries, its English counterpart, the Royal Society (1662), never regimented English letters (Parkhurst Clark 1987).
}

${ }^{5}$ Compared to Europe, the relationships among state, market, society and the arts developed differently in the United States (Parkhurst Clark 1987; Zolberg 1990). The tradition of and kinds of support structures that had been established in Europe were absent. There was no established aristocracy; until well into the twentieth century, the state was relatively weak; and there existed no single religious institution as prominent as the Roman Catholic Church on the European continent. On the whole, what public sources there were tended to be allocated for cultural institutions such as museums, and came from municipalities and states, controlled by local elites. See, among others, DiMaggio (1982).

\footnotetext{
${ }^{6}$ Viala (1985) and Parkhurst Clark (1987) provide analyses of the role of literary (state) patronage in seventeenth and eighteenth century France, while Griffin (1996) considers the role of literary patrons in England between 1650 and 1800 .

${ }^{7}$ For the developments in England, c.f. Laurenson (1972), Gross (1991), Altick (1963), Watt (1957), and Williams (1961). Gedin (1977) traces the development of the literary market in Denmark, Norway, Finland, and Sweden, while Tebbel (1975 and 1978) sketches the development of the American publishing industry between 1865 and 1940. Rarisch (1976) details the development of the literary market in nineteenth-century Germany. Berman (1983) and Parkhurst Clark (1987) provide interesting accounts of how the emergence of a literary market affected the social status and work of writers in Germany and France, respectively.
}

${ }^{8}$ White and White (1993), Moulin (1987), Lenman (1997), and Stolwijk (1998) detail the development of the art market in nineteenth-century France, Germany, and the Netherlands, respectively. 
notion of free, disinterested, spontaneous 'creation', founded on innate inspiration, appear to be just so many reactions to the pressures of an impersonal market.

Thus, the appearance of an anonymous 'bourgeois' public, and the proliferation of new marketing strategies coincided with the rejection of bourgeois aesthetics and with the methodical attempt to distinguish the artist and the intellectual from other commoners by positing the unique products of "creative genius' against interchangeable commodities. Since that time, the production of culture has come to consist of two differential systems: one of restricted production and one of large-scale production (Bourdieu 1985). The former field (for instance poetry) tends to evolve toward the model of a 'reputational' profession (where professional hierarchy is based on reputation), with the ultimate reward becoming part of the 'canon'. On the other hand, large-scale production is similar to 'market' professions, where hierarchy is based on market success (DiMaggio 1987a) .

From about the mid nineteenth century, different styles and movements began to follow each other thick and fast, as innovation, originality, and breach of tradition became the norm. No longer bound by a set of self-evident rules imposed upon them by one or another external authority, writers and artists became subject to 'aesthetic uncertainty.' No longer did they agree on form, technique, substance, and style, or on criteria by which to differentiate art from non-art or good works from mediocre ones. The combined effect of this lack of generally accepted standards and the requirement for originality and innovation was to reinforce aesthetic uncertainty among writers and other artists, and to turn critics and other experts into the most qualified judges of aesthetic value.

Thus, writers and artists gradually faced a new situation, offering more freedom, but at the same time rendering their lives more precarious and subject to impersonal market relations and uncertainties (Pelles 1963; Sutherland 1976; Laurenson 1972; Pevsner 1970). In the twentieth century, increasingly complex markets developed encompassing commercial producers, distributors, and outlets; economic agents took many forms, including entrepeneurships, corporations, and conglomerates. At the same time, technological developments, such as the radio, offset printing, TV, and advances in the electronic and computer industries, empowered an already extraordinary complex institutionalized base for the production and dissemination of the arts and altered significantly the nature of their consumption.

\section{Modern forms of patronage}

It should not be overlooked, however, that certain modern forms of patronage have to some extent taken over from the traditional relationship. Writers may write on commission for television, for example (Bradbury 1971; Fohrbeck and Wiesand 1972; Sutherland 1978). ${ }^{9}$ Another modern corporate patron for writers is the university, especially the American university, which in the past decades has supported many authors as 'creative writers' or 'writers-in residence.' The same holds mutatis mutandis for other categories of artists. Photographers may be employed by newspapers or advertising agencies, instead of relying on freelance earnings for 'art' photography (Rosenblum 1978). Painters are often commissioned by industrial corporations to execute works, or employed as community artists or as 'artists-in-residence' at universities (Berry 1970; Braden 1978; Dubin 1987; Mennell 1976).

And perhaps the most important development in the twentieth century has been the growth of government patronage of the arts (Minihan 1977; Pearson 1980; Useem 1976; DiMaggio and Useem 1978). In the nineteenth century, the state as an artistic patron more or less disappeared in most Western countries, but with the postwar welfare state it returned, and in some areas - such as opera - became more firmly entrenched than ever. In most of Europe and North America, state patronage operates at the moment through national and regional arts councils, funding bodies, and associations, in conjunction with local institutions and authorities; through grants to artists and writers; and funding for projects. Although one would not expect any direct intervention by the respective 'patron' in what the artist actually produces, it is clear that funding bodies are no more neutral than any social organization, and that the success of some artists in gaining sponsorship and the failure of others is likely to be related to the type of

\footnotetext{
${ }^{9}$ Bradbury (1971) notes that the BBC is probably the richest and largest patron in the history of literature.
} 
work they do (Pearson 1979). That is to say, it is still true in our day that art which is successful in reaching a public by being 'bought' achieves this through various social structures and processes, and not simply because it is, in some sense, just good art.

\section{The formative role of mediators}

With the development of the market as the most important structure for artistic creation and distribution, people and institutions who are in effect mediators have taken on an increasingly crucial place in the careers of writers and other artists. They became vital agents to them, not only with respect to the immediate problem of economic survival, but also the valuation of their work and the establishment of their reputations. The shaping influence of these mediators, in particular their legitimizing power, has led some sociologists to coin them 'co-producers' of the work of art (Bourdieu 1980). For visual artists, mediators include galleries, auction houses, curators, art journals, critics, and other artists. Counterparts for writers include agents, publishers, editors, critics, reviewers, book sellers, libraries, and fellow writers. The interplay among them structures the individual and collective situations of writers and artists.

Other institutional systems serve less obviously as instruments of mediation. During the 1970s, books began to be developed in conjunction with movie and television presentations. The Hollywood movie industry had used literature from its inception (Tebbel 1978), but in the late 1970s, the simultaneous development of a work in print, movie, and television became widespread practice. Thus, book sales were tied in directly to the success of non-print presentations. Today, film companies and television networks are capable of greatly enlarging novelists' audiences (Whiteside 1981; Brasey 1987) and keeping their work in the public eye long after their death (Rusch 1999). Educational institutions also mediate the relationship between writers and readers. School books tell students whom to read and what kinds of things to say about texts. ${ }^{10}$ Curricula emphasize some works to such an extent that they become institutionalized as canonical literature. All the while, educators' book orders help to determine which books stay in print and which enjoy repeated printing.

The past decades witnessed a flood of research on how mediators in the field of art and culture shape individual works and whole careers. Much attention has been paid to two interrelated aspects of the work of mediators and their effects on artistic careers and products: gatekeeping and decision-making. ${ }^{11}$ These concepts originate primarily from research into news production (White 1950; Breed 1955; Tuchman 1978), but they can be applied more or less equally to other areas of cultural production (Hirsch 1977; Peterson 1994). With respect to news, the chain extends from 'noticing' an event in the world, through writing about or filming it, and preparing a news item for transmission. In the case of a book, a movie, a television show, or a piece of popular music, a similar chain extends from an idea in someone's head, through an editorial selection process and many phases of transformation, to the final product.

Both feminist thinking and the deconstructionist concern with the artificiality of the canon have drawn attention to the selectivity of publishers and other gatekeepers and a number of studies on the fate of female artists have been carried out form the perspective of gatekeeping or decision-making.

Tuchman (1989), for example, provides a fascinating study of invasion and inclusion. She shows how Victorian women writers were 'edged out' of their dominant authorship position, once men had caught on to how profitable writing fiction could be. Male editors and literary critics worked together to elevate the aesthetic status of the novel form in part by denigrating the contributions of the early female novelists.

\footnotetext{
${ }^{10}$ For an analysis of the part played by the educational system in the production of consumers endowed with a propensity and aptitude to consume canonical works and in the reproduction of the unequal distribution of this propensity and this aptitude, and, hence, of the distinctive value of these works, see Bourdieu and Darbel (1969) and Bourdieu (1984).

${ }^{11}$ These activities can also be described as 'selecting' and 'processing' (McQuail 1994: 212).
} 


\section{Gatekeeping}

The term 'gatekeeping' has been applied when the focus is on judgments whether to admit persons or works into a cultural field; it has to do with accepting or rejecting works or their creators and the consequences of these choices for subsequent works and creators. Gatekeepers in the arts can exercise their function at different stages, inspired or forced by a variety of considerations and constraints. In the case of literature, publishers can prevent manuscripts from reaching the market, as can censorship of the type which demands pre-publication licensing. On the other hand, gatekeepers may play their selective part once books have been published; their fate depends in part upon the decisions made by critics, distributors and, again, censors - although this time of the post-publication variety. Driving forces behind gatekeepers' decisions range from political and moral concerns, commercial interests, to 'purely' aesthetic motives. In most cases, they consist of a mixture of these.

\section{Censors, publishers, editors, and dealers}

The effects of political and legal constraints on artists' work and careers has been one of the pervasive themes in the sociology of the arts. ${ }^{12}$ Numerous studies have demonstrated how government bodies and laws, either through the carrot of support or the stick of censorship, accomplish exclusion and channeling in literature and other cultural domains. Understandably, the focus has been on how censorship operates to reduce freedom of expression, but, as Speier (1977) notes, censorship may also provide the stimulus for more complex symbol expression, illusion, euphemism, analogies, and the like.

In-depth analyses of publishing houses have shown that their capacity to exclude or promote can hardly be overestimated (Powell 1985). Coser et al. (1982), in their comprehensive study of the contemporary American publishing industry, argue that writers are only the 'junior partners' in a world where publishers and editors reign supreme. Working from in-house observations and hundreds of interviews, they describe in detail what gets into print and why and how publishers and editors in their roles as gate keepers of culture more or less decide what ideas enter the mainstream of society. In their studies of romance novel publishing, Markert (1984) and Thurston (1987) show that editors sometimes play a much more active role than is implied in the concept of gatekeeping, which can be described as 'gatemaking.' In the 1970s, the editors of a number of American romance publishing houses consciously articulated a new formula for romance novels, and thus provided opportunities for a whole new set of authors. In the nineteenth century, there is a good deal of evidence that writers took into account the demands of the powerful mediators of that time in actually writing their novels. Some examples of this are documented in Sutherland (1976). For instance, the demand by the extremely powerful circulating libraries for the three-decker novel forced writers to comply with this form. Novels intended for serial publication in weekly issues were written in that form, for example, with cliff-hanging endings for each episode.

Research into the world of the visual arts has revealed how art dealers, gallery owners, and curators play a similar part as publishers and editors, determining to a large extent which works, artists, and schools come before the public as well as urging artists to produce certain types of work (Bystryn 1978; Moulin 1987; Greenfeld 1988; Alemann 1997). Simpson (1981) details the role of professional dealers or gallery owners in Soho who act as gatekeepers to the contemporary New York art world and whose major activity consists of matching collectors and painters. Like independent agents spanning organizational boundaries in the recording industry, dealers seek artistic 'talent' in one group and corresponding buyers in a different group. Successful Soho artists are the ones who recognize the privileged 'entrepreneurial' position of their dealer and listen to his/her feedback about clients' aesthetic sensibilities.

\footnotetext{
${ }^{12}$ Watt (1957); Lowenthal (1961); Thomas (1969); Swayze (1962); Boyer (1968); Clor 1969; Griswold (1981); Davis (1984); Dubin (1992).
} 


\section{Critics and reviewers}

Another line of research has shed light on the formative role of criticism in the establishment and survival of artistic reputations. Writers/artists and their critic-advocates seeking recognition make claims of creativity, quality, innovativeness, excellence - that is genius. While sociological theory and method are not useful in identifying 'genius' in works or their makers, they have proved very helpful in demystifying canon formation, the processes by which claims of 'genius' or 'quality' come to be agreed upon and reputations established. A number of specific studies can be cited: Van Rees (1983a) details how texts, in order to be regarded as being of high quality, have to pass through the selection filters of three distinct types of critics: reviewers, essayists, and academic critics. Their complementary activities determine to a great extent which texts are regarded as legitimate forms of fiction; what rank they are supposed to occupy within the hierarchy of literary works; and what statements count as proper and relevant ways of characterizing these texts. Among these three types of criticism, the day-to-day reviewing of new literary books has the lowest status. Nevertheless, the daily reviewers have one important advantage. They are the first gatekeepers to evaluate the literary text after its publication. It is true that the readers and editors of the publishing houses come before them, but it is also true that the essayists and academics arrive on the scene later on - sometimes very much later (Verdaasdonk 1985). Janssen (1997) examines the selection Dutch reviewers made from the supply of new fiction titles in the 1970s and 1990s and sheds light on the conditions under which they decided whether to review or ignore certain works. Rosengren (1987) shows that reviewers may have a considerable influence over the literary frame of reference of later generations of reviewers, essayist and academic critics (just as their own frame of reference has largely been shaped by previous generations of critics). The question of how the value and nature of literary works come to be agreed upon by critics and writers' reputations established is illuminated in a number of case studies (Van Rees 1987; Rodden 1989; Van Dijk 1994; Janssen 1994).

A comprehensive study of the contemporary French art market (Moulin 1987) demonstrates how critics 'discover' new artistic geniuses all the time in a promotional role that plays a critical part in the distribution of paintings to sophisticated buyers who would not dream of being influenced by advertising. Other studies of the contemporary art market in Israel (Greenfeld 1989) and New York (Wolfe 1975; Crane 1987) underline the promotional capacity of critics as well as their leading role in the construction of aesthetic value.

\section{Cross-cultural exchange}

Gatekeepers are also important when artistic expressions created in one art world are introduced in another (Griswold 1992; Nies 1996; Voorst 1997). Griswold (1992) shows how English publishers, acting as gatekeepers for the work of Nigerian novelists, have strongly affected the work that these novelists produce. In selecting novels that fitted an outmoded model of tradition-versus-modernity, they have created a very influential genre which is at odds both with the reality of Nigerian life and with the intentions of most Nigerian novelists. In another study, Griswold (1987) considers the export of meaning beyond national borders and the transformations of meaning which occur through this process. Comparing American, British, and West Indian reviews of the work of the Barbadian novelist George Lamming, she finds stunning cross-cultural divergences. Race is highlighted in American reviews of Lamming's novels, yet virtually ignored in British discussions, which focus instead on the novels' language and literary qualities. In contrast to both, West Indian reviewers concentrate on questions of personal and national identity. Lowenthal (1964) details how Dostojevski has been reevaluated by German literary critics to fit with the changing moods of the German intelligentsia. Rollin (1976) outlines mechanisms by which works of popular culture are transevaluated as literature.

In one way or another, all of these researchers show that the evaluation of works and their makers depends on the (shifting) standards and tastes of various sorts of gatekeepers. 


\section{Decision-making}

The concept of gatekeeping refers to the capacity of mediators to exclude or promote. However, cultural industries from book publishing to television regularly make decisions other than choose/reject, altering or recontextualizing works at different stages of the production process. When the focus is on the way that works are changed as they move from being ideas to being finished products, the term decision chain is more appropriate (Ryan and Peterson, 1982). Ryan and Peterson have drawn a model of the decision chain in the popular music industry, which consists of a number of separate links: from song writing to publishing; from demo tape to recording (where producer and artist are selected); from recording to manufacturing and marketing; from there to consumption via radio, TV, juke-box, live performance or direct sales. In this case, the original ideas of song-writers are filtered through music publishers' ideas concerning presentation (especially artist and style), which then play a part in promoting the product in several different markets. Processing takes play on the basis of a prediction about what the next 'gatekeeper' in the chain will think, the key being the overall product image. The authors note that at each decision point, the question is not so much 'What have I got to say?', or even 'What does the music fan want to hear?' but rather, 'What changes need to be made to get the song accepted by the next node in the decision chain?". So, for example, in the field of country music, the question for the record producer in the early 1980s was how to shape a song so it would be played by virtually all male disk jockeys, even though the majority of country music record buyers where then women.

In the same vein, Cantor and Cantor (1991) detail how the basic character of a television series can be altered even after it appears on the air. Gitlin (1983) and D'Acci (1987) offer absorbing case studies of the twisting fate of a relatively unknown series entitled American Dream and the popular 1980s police series Cagney and Lacey. Their studies demonstrate how the numerous changes in both shows from plot line and casting to locale and tone - were also made to meet the needs and interests of people along the decision chain.

\section{Occupational characteristics and their implications}

\subsection{The arts: a profession?}

Owing to the personal commitment writers and artists typically have, and the considerable autonomy they apparently enjoy in their work, they are often considered to be professionals. This is also reflected in the occupational categories that are distinguished in the sociology of work and in government statistics. For example, the U.S. Bureau of the Census counts 'writers, artists, and entertainers' among the category of 'Professional, technical and kindred workers' together with, among others, accountants, architects, engineers, dentists, doctors, lawyers, college and university teachers, scientists, and librarians (Hall 1994).

However, the occupation of writer or artist differs from other professions in important ways and is not in the strict sense a profession at all. This becomes clear when we consider two key characteristics of professions that have frequently been mentioned in the sociology of work and occupations: the existence of a systematic, certified knowledge base and a high degree of occupational control.

\section{No systematic body of certified knowledge}

A high degree of generalized and theoretical knowledge is considered to be one of the distinctive characteristics of professions: expertise and skills, based on a systematic body of certified knowledge, serve as the practitioners' claim to professionalism and autonomy (Barber 1963; Goode 1960; Wilensky 1964; Greenwood 1966; Hall 1994). However, in the case of writers and other artists, it is impossible to define the optimal knowledge base to substantiate their claim to expertise. In the first place, it is doubtful whether such systematic knowledge exists, though there are technical skills. Secondly, unlike the 
knowledge base of the established professions, 'the knowledge' of the artistic professions is neither cumulative nor codified. Thirdly, some believe that the knowledge involved in art making is inherent and that the main difference between laymen and professional artists is that the latter are trained to develop techniques and regard them as their specialized domain. Moreover, the skills involved in, for example, creative writing, are not normally supposed to be ones that can be directly taught, although the past decades have witnessed all sorts of attempts to teach them - from the writing courses and handbooks advertised in the media to the growth, particularly in the United States, of the 'creative writing class.' But writing is still primarily viewed as an activity which depends very much upon intuitions and imaginative gifts that may be stimulated and encouraged, but which cannot normally be easily passed on. In journalism, one of the expanding trades of the last two centuries, some instruction exist; and in certain forms of writing - like television script writing - a good deal of the practice has become codified so that instruction could occur. But a distinction is normally made between such 'practical' forms of writing and 'imaginative' writing, with the latter regarded as a matter of personal quality, inspiration, and self-acquired skills. Finally, one of the inherent problems of the artistic professions is how to define artistic talent or artistic skills. In the arts, the skills presumably indicating talent and necessary for professional achievement are neither specific nor clear.

\section{Relative absence of occupational control}

The concept of 'occupational control' refers to 'the collective capability of members of an occupation to preserve unique authority in the definition, conduct and evaluation of their work' (Child and Fulk 1982: 155). Such control is exercised by only a handful of professions that are able to restrict access to the profession's knowledge base. Both law and medicine provide services based on the authority of expertise on keeping their professional knowledge at arm's length from their clients. This practice differs both from 'people-working' professionals, who share their knowledge with clients, and from other professionals, such as accountants, whose work activities are directed toward serving the goals of the administration of the organization that employs them. Artists generally do not possess a monopoly of access to the knowledge that is needed to perform their tasks. The same applies to the evaluation of artistic work. Although artists are often in a position to pass judgments on artistic talent and their fellow-artists' work (Oosterbaan Martinius 1990), they by no means have a monopoly of evaluation: audiences and, especially, mediators such as critics and other qualified experts have the right and power to make value judgments about artistic work as well.

Occupational control also includes the capacity to determine the conditions of entry to and exit from the practice of an occupation. The closed professions, such as medicine or law, maintain registers of certified practitioners. Peer-control determines, most often by means of qualifications, who can enter or pursue the profession and use the title: in the case of misconduct, they can also annul this entry. The arts are clearly different: anybody at all is free to enter the trade and call him/herself an artist without a formal degree or any officially recognized demonstration of competence. This has not always been the case. In some countries and during some eras, the arts were characterized by fairly tight occupational control, both in the number of recruits and in the course of their careers. During the guild era in Europe, for example, no apprentice could change masters unless his first teacher agreed to break his contract, and all apprentices had to remain with their master for three years. However, in twentieth-century Europe and the United States, the arts were characterized by a relative absence of centralized occupational control, compared, for example, to the medical profession in these countries, with its institutional self-awareness, its standards of competence and discipline, and its relatively stabilized recruitment.

\section{Other indicators of incomplete professionalization}

Also by other standards, the artistic occupations hardly qualify as a profession. According to Wilensky (1964) an occupation can be counted among the professions if it has the following characteristics: most practitioners have a full-time job; there are special institutes for vocational training as well as profession- 
al associations; the occupation is recognized and protected by the state and it has a code of ethics. On each of these scores, artists are clearly the inferiors of professionals such as doctors, lawyers, or architects. Many artists combine their art work with a second job. Most art forms have institutes for vocational training but autodidacts have always taken an important place in all art fields. Although there are professional associations, many writers and artists do not join them and membership is not a prerequisite for practicing the occupation. The absence of prescribed vocational training and professional associations implies that recognition and protection of the artistic professions are not practicable, while an ethical code only exists in a very abstract sense.

\section{Aesthetic uncertainty and status indeterminacy}

As mentioned earlier, modern art and literature are characterized by the absence of both generally accepted criteria for evaluating artistic products and clear guidelines as to how to create them. As a result of this lack, writers and other artists find themselves in a position of aesthetic uncertainty. Moreover, as Anheier and Gerhards (1991) point out, the absence of a formal professional structure, in conjunction with the unpredictability of the market, imply that the social position of writers and other artists is characterized by status indeterminacy. Their social prestige and income are subject to great variation, so that today it is nearly impossible for sociologists to assign the artistic occupations a prestige score.

\subsection{Economic position of artists}

Having established that the arts differ from other professions in a number of ways, what can be said about the economic position of contemporary artists as an occupational group?

Since the 1960s, an important line of research has emerged into the social and economic conditions of living and practising artists, which can be summarized under the heading of 'Status-of-the-Artist studies' (Kartunen 1998). These studies are usually commissioned by public arts administration bodies or artists' associations, who naturally attach their own policy-related objectives to them, and who often expect to gain legitimacy through them. In most cases, they are carried out by social scientists in the form of massive surveys of statistically valid samples taken from the total population of artists (or from the population of practitioners of a specific art form.) Their approach is typically 'hard', quantitative, the aim being to asses artists' conditions of life and the effects of public policies on them. In the 1960s and 1970s, in particular, these studies were carried out in the spirit of the positivist sociology of art, aiming at practical applications in cultural policy. Typical examples include the extensive reports on the social status of writers (Fohrbeck and Wiesand 1972) and artists in Germany (Fohrbeck and Wiesand 1975). In recent years, both the sociology of culture and the emerging discipline of cultural economics have yielded important contributions to this area of research (Moulin et al. 1985; Throsby 1986; Jeffri 1988; Finnish Arts Council 1988-1996; Throsby and Mills 1989; Wassall and Alper 1992; Throsby and Thompson 1994; Towse 1996).

Status-of-the-artist studies have produced a mass of statistical data on artists' position in the United States, Canada, Australia, Great Britain, Germany, Finland, and other European countries, i.e., figures about artists' earnings; about the effect of education and training on artists' incomes; about unemployment rates among artists; about time allocation between artistic work and work in the non-arts sector and about artists' social characteristics. They have also provided data on artists' attitudes: satisfaction or otherwise with the promotion of their work; why they work less than they would like in their chosen artistic profession; what support they would like from funding bodies, etc. Drawing on this rich body of research, a number of observations can be made as to how artists fare in comparison to other occupational groups. 


\section{Labor force of artists}

We have already noted that the arts in twentieth-century Europe and the United States are characterized by a relative absence of centralized occupational control. Moreover, in these countries, the market for literature and for other art forms has been rapidly and vastly expanding in the postwar period. This combination of an expanding market and an absence of tight controls suggests that the arts - fine and commercial - must recruit in a very generous, if not excessive fashion. Census data from the United States confirm this. The U.S. Bureau of the Census defines 'artist' quite generally. The category includes actors and directors; architects; authors; dancers, designers; musicians and composers; painters, sculptors, craft artists and printmakers; photographers; radio and TV announcers; teachers of art, drama and music in higher education; and other artists (Heilbrun and Gray 1993). In the 1980 federal census, the number of people who defined themselves as being a member of one of these occupational groups was about $1,020,000$, which represented an increase of about $46 \%$ over the total reported in the 1970 census. While it is widely known that the professional and technical professions are increasing dramatically (the growth of the labor force of these categories in U.S. was $40 \%$ in the 1970s), artistic occupations are increasing at an even faster rate. Artists have comprised an increasing proportion of the U.S workforce over the last forty years, rising from 0,73\% in 1950 to 1,31\% in 1990 (National Endowment for the Arts 1992).

Census data also indicate that U.S. artists are relatively young (the median age in 1980 was 34), predominantly male (57\% in 1991), and predominantly white (92\%). ${ }^{13}$

\section{Working conditions and employment}

The occupational structure of most arts activities is such that there are relatively few regular jobs. Only a minority of artists have full-time, long-term contracts. Creative artists making things for sale (writers, painters, sculptors, composers, craftspeople) mainly work as independent, self-employed contractors, while performers (actors, musicians, dancers) are mostly employees without job-security when they work for money. Hence, as Towse (1996) notes, the level of employment in the arts cannot by measured by the number of jobs, nor can unemployment be measured by the gap between jobs and vacancies. Moreover, self-employed artists cannot, from an official point of view, be unemployed, as selfemployment is viewed as a business-like activity, which either yields sufficient income for the 'firm' to survive or it closes down. Towse argues that many artists, in a number of ways, are indeed like businesses: they must invest resources in preparing whatever it is they supply (developing skills, practising, rehearsing, making sketches), and they spend time and money promoting themselves, showing their work, going to auditions, approaching agents, dealers, and publishers. Such preparatory and promotional activities do not constitute hours of employment.

Many surveys of artists have gathered information both on the numbers of hours spent on artistic activity and on paid employment, and about periods of unemployment. Artists have been shown to spend long hours at their art work, part of which is unpaid (performers practising to maintain their skills, other creative artists spending time producing work that is not for sale). For example, in Australia, about 70\% of artists work longer in total than the standard full-time working week. In the United States, only about $25 \%$ of artists work more or less full-time at arts work, and it would appear that a majority of those working less than full-time in their chosen professions would prefer to spend more time in the arts but are deterred from doing so by the need to earn an income elsewhere (Throsby 1994). Thus, many artists, in effect, are under-employed: they are unable to obtain as many hours of paid arts work as they would be willing to do at the going rate of pay.

\footnotetext{
${ }^{13}$ Cf. National Endowment for the Arts (1982/1992). Throsby (1994) notes that these proportions are found to be somewhat smaller in surveys targeted specifically at practising professional artists.
} 


\section{Multiple job-holding}

As many writers and artists cannot earn enough from their principal artistic occupation, they engage in other kinds of work to support themselves. The usual break-down of this 'multiple job-holding' of artists is one between arts work, arts-related work, and non-arts work. Arts work concerns work directly related to the artistic profession, such as sales, commissions, and subsidies for writers and visual artists. Artsrelated work concerns activities such as teaching, reviewing, translating, and giving advice on artistic matters. Non-arts work includes all labor-market activities outside the arts sector (Throsby 1994 and 1996). Wassall and Alper (1992) review a number of surveys which document the extent of multiple jobholding by artists, including their own 1981 survey of over 3,000 New England artists which found only $24 \%$ of artists holding no non-artistic job. They observe that as artists' careers solidify as they grow older, more time is devoted to arts work, though it is not clear whether this results from greater career success of existing artists or from the less successful dropping out.

\section{Artists' earnings}

A comparison of artists' incomes with those of the average worker using census data may not reveal a substantial difference, in particular if total (arts and non-arts) income is used as the measure of artists' earnings. Comparisons with more specific occupational groups, however, do indicate a substantially lower level of mean and median earnings among artists than among workers of similar educational and professional standing. Thus, in 1990, the median weekly earnings of all full-time workers in the United States was $\$ 415$, while that of all full-time artists was $\$ 499$. In the same year, however, the median weekly earnings of all full-time managerial and professional workers, a group broadly comparable with artists in terms of educational attainment, was $\$ 615$ (Throsby 1994). Heilbrun and Gray (1993) note that the earnings of U.S. artists with a college degree tend to be no higher than the earnings of professional workers who only have a high school diploma.

The finding that the earnings of writers and other artists tend to lag considerably behind those of comparable workers is robust over several countries and holds for almost all art disciplines. While such comparisons are seriously hampered by all sorts of definitional problems (Who is an artist and who is not?, see Kartunen 1998) and do not control for other systematic differences between occupational categories, they are at least consistent with analyses of survey data which indicate that most artists suffer a significant income penalty. Artists' earnings also prove to be more unequally distributed than those of other groups. Some artists do earn high incomes from artistic activity but they are a minority. The majority earn considerably less than they would outside the arts, and the sums involved frequently fluctuate from year to year.

So artists' earnings are not only lower on average than those of comparable workers, but they are also more variable, both across time for an individual artist, and across artists at a given point in time.

\section{The pay-off of education and other human capital variables}

Considering the relation between education and income, a mainstay of human capital theory, the arts also differ from other occupations. Within any group of workers, we would normally expect that more highly educated individuals would earn higher incomes. There is mounting evidence, however, that the returns to education are in general much lower in the arts than elsewhere. The same holds for other 'human capital' variables such as (on-the job) training and experience or age. Towse (1992) estimated 'earnings functions' using data from a survey among artists in Wales. An 'earnings function' shows the effects of a number of variables, such as hours of work, level of education, length of training, and experience, on income. The only statistically significant influence on arts earnings proved to be the time artists (of all types) spent on arts work. Experience or level of education apparently exercised no influence on arts earnings. Throsby (1992) established that Australian artists' earnings were also affected by gender. Income from both arts and non-arts work was lower for female artists, even after all other sources of varia- 
tion (hours worked, age, educational attainment) were accounted for. The gender-effects on arts income were considerably stronger for creative artists than for performing artists, suggesting that females were discriminated less in the performing arts in Australia than in other artistic fields.

Disaggregation of artists' earnings decomposes the effect of education for the three relevant markets to which artists supply their labor (Throsby 1996). This shows that the effect of schooling is greater for arts-related work and non-arts work than for arts work. The same holds for the effect of (onthe-job) training and experience.

\subsection{Coping with uncertainty}

Summarizing the previous paragraphs on the arts as an occupation, we can conclude that artists' contemporary position is characterized by economic uncertainty, status indeterminacy, and aesthetic uncertainty. The difficulties and dilemmas that modern writers and artists face are complex and numerous: the danger of 'selling out' in an effort to acquire financial security; increasing specialization that is counter craft and art traditions; intense competition for scarce resources; the absence of a credentialing system, which makes it impossible to control the terms and conditions of entrance by aspiring artists; and the unpredictability of changing styles and fashions. Hence, the question arises how writers and artists manage to cope with such uncertainties, for many prove indeed capable of sticking to their chosen fields of art work. Research into their careers suggests that social ties or networks play an important part in this respect.

We have already seen that many artists, apart from their primary artistic work, have second jobs. In part, this multiple job-holding explains how writers and other artists survive financially and cope with economic uncertainty. ${ }^{14}$ It allows them to meet a minimal income constraint and to spread the risk of income uncertainty. Although second jobs entail that many writers and artists can spend less time on their arts work, arts-related jobs (such as advising on artistic matters, critical writing for the press, etc.) have one big advantage that should not be overlooked. They help to establish and maintain social relations with relevant agents in their chosen art field (fellow-artists, publishers, editors, dealers, curators, etc.) and thus to increase what can be called their 'social capital' (Bourdieu 1983): 'the whole range of resources that flow from the possession of a more or less institutionalized enduring network of relations of mutual acquaintance and recognition.'

Of course, social ties or networks are generally important for people. Family members, friends, acquaintances, and colleagues provide individuals with social, emotional, and financial support. Through their linkages with a variety of other people and groups they obtain valued resources, including information, advice, critical feedback, and acknowledgment for a job 'well done.' Research into people's position in the labor market shows that involvement in social networks considerably facilitates their careers (Granovetter 1995; Boxman 1992; Flap and Tazelaar 1988; Bernasco 1994).

Thus, social networks have universal significance for the life and work of individuals, but they have a special significance for writers and other artist, who must operate in a world where most activities take place on a freelance basis and are not controlled by formal organizations, agreements, or criteria. In many situations, they cannot, therefore, appeal to a higher, impartial authority, but have to rely primarily on each other for the fulfillment of their needs and ambitions.

In the arts, as in other fields of incomplete professionalization, largely informal social networks fulfill several functions that in other occupations would be served by formal, institutionalized mechanisms. In general, such networks may reduce economic uncertainty, status indeterminacy, and aesthetic uncertainty for their members:

- they regulate access to power, resources, institutions, and persons (Kadushin 1976; (Coser et al. 1982; Faulkner 1983; Ridgeway 1989; Verdaasdonk 1994) and promote members' monopolistic control over scarce job opportunities (Peterson and White 1989);

\footnotetext{
14 For many writers and artists, parents or partners also provide essential financial support (Towse 1996).
} 
- they channel information, give support and advice, and provide service and resources (DiMaggio 1987a; Powell 1985);

- they provide rituals, such as 'name-dropping' which help to construct a shared identity (Douglas and Isherwood 1979);

- they help establish an artist's self-image, social position, reputation, and prominence (Anheier and Gerhards 1991 and 1991b; Anheier, Gerhards, and Romo 1995; Janssen 1998).

- they help to maintain standards artistic standards for insiders (Peterson and White 1989) and provide ideas about styles and techniques, sources of criticisms, and validations for an aesthetic approach or artistic innovation (Meyer 1967; Crane 1989; Ridgeway 1989).

\section{Recruitment, socialization, and career development of artists}

A final topic that has received a lot of attention from social scientists is the question of how people become (successful) artists.

Choosing a career is one of the most important, and perhaps most difficult tasks, faced by individuals. Why would anyone choose a career that entails notoriously low earnings, long and uncertain hours, and arduous preparation and training. Why choose a job that forces the majority of practitioners to have second jobs, and in which fame and fortune are only reserved to a tiny minority? We have seen that careers in the arts tend to have just such characteristics, but we have also seen that the arts recruit in an almost excessive fashion. In many occupations, the process of recruitment can be readily understood, but there is much vagueness concerning the recruitment of artists. A number of models of career choice in the arts have been proposed, but sound data to substantiate them are in short supply.

Nonetheless, as Griff (1970) notes, this does not imply that people 'somehow drift into art. There exists a whole set of social paraphernalia for getting persons committed to their artistic identities.' The question of how people become artists, in more than one respect, is and always has been a structured affair, and this was particularly true in earlier centuries. It is true in some obvious ways: for example, becoming a full-time writer involves literacy (and therefore education, not always available to all sections of the population) and leisure (and therefore some kind of secure income or means of support). In the light of this, it is not surprising to learn that in the nineteenth century most writers were of middle class origin (in most cases from a professional family) and had gone to public school or a university (Williams 1961; Altick 1962; Bradbury 1971; Laurenson 1972). It is also understandable that a large proportion of novelists in that century were women, the newly leisured wives of the wealthy middle classes (Laurenson 1972; Tuchman 1975; Bonham-Carter 1978).

In the twentieth century, the recruitment of artists became less rigidly structured. The class background of writers became less homogeneous than it once was (Bradbury 1971; Laurenson 1972), and much the same can be said for music and painting, where it was once almost a prerequisite or at least an advantage to have been born into a musical or artistic family (Nochlin 1973; Tuchman 1975; Greer 1979). Nonetheless, in the twentieth century as well, familial values and pressures have been found to play an important part, both in the initial choice for a career as a painter (Griff 1970; Getzels and Csikszentmihalyi 1976; Top 1993), composer (Nash 1989), dancer (Sutherland 1989), or actor (Levy 1989) and in the choice for a specific artistic career path or trajectory. The same holds for experiences in grammar and high school (Griff 1970; Getzels and Csikszentmihalyi 1976), peer groups, and occupational role models (Levy 1989). There have also been studies on how, having chosen this career, art students are taught, and on the role of the art school and mentor-protege relationships in 'shaping' artists (Strauss 1970; Tas 1990; Heilbron 1992).

Thus, the way in which artists and writers take up their careers and the particular values and attitudes they bring to them from their family and class backgrounds affect their career choice and the kind of work they do as artists. And if specialized training is involved, the processes of the institutions of 
training are also likely to 'form' the artist and influence the direction of his or her development. Of course, artists' training and socialization is not finished once they have left school and have entered the occupation. Occupational practice confronts them with the norms, conventions, and practices current in their chosen art field and it is 'on the job' that they gradually acquire and develop the ability to function in accordance with them.

\section{Parameters of success}

The question of what determines success or failure in the arts has puzzled many scholars. Some of their answers have already been presented in the previous sections. Most social scientists agree that artistic talent is only one variable and not the most important. Artists' fame and fortune is assumed to be largely dependent on the workings of the complex 'cultural apparatus' of producers, distributors, and promotors standing between them and their audiences. Gatekeepers, such as publishers, decide whether their work becomes available to a public, while its meaning and value are constructed by qualified interpreters and judges such as peers, critics, and post-processors (see section 3). Moreover, the possession of an extensive and varied network of personal relations is believed to foster artists' careers, for example, by facilitating access to influential art world members and institutions (cf. section 4.3). In addition, artists' family members and partners have been found to play a significant part in their careers. For example, Simpson (1981) has shown that the quality of relationships with partners tends to be quite different for successful artists on the one hand and unsuccessful artists on the other. The former tend to have supportive partners, while the latter have partners that are overprotective and smothering.

But artists' fate is not totally dependent on such other agencies and forces. Comparative studies of successful and less successful writers have shown that the former tend to take a far more active part in the image-building around their work (Janssen 1994 and 1998; Van Dijk 1999). They are the ones who, whenever there is an opportunity, express their views on the nature and function of art; reveal their own artistic intentions and premises; comment on critical interpretations of their works; provide criticism with new material for interpretation by pointing to 'neglected' aspects or themes of their work; explain their relationship to contemporary colleagues and predecessors, etc. Moreover, successful writers and artists tend to engage more often in all kinds of arts-related activities (reviewing, advising on artistic matters, etc.) than their less successful counterparts (Janssen 1998). As a result, they have at their disposal more elaborate social networks in their chosen art field and they enjoy all the advantages and opportunities that wide-ranging networks offer their members.

Other studies suggest that whether or not artists take such an active part and whether their selfpromotional efforts have the desired effects, among other things, strongly depends on their familiarity with the existing conventions, opinions, and relationships in a particular field. Becker (1982) argues that with no professional training and no contact with the conventional art world, 'naive artists' do not learn the conventional vocabulary of motives and explanations for their work. Since they cannot explain what they are doing in conventional art terminology, naive artists frequently have trouble with people who demand an explanation. On the other hand, 'integrated professionals' have the technical abilities, social skills, and conceptual apparatus necessary to make it easy to produce art. Because they know, understand, and habitually use the conventions on which their world runs, they fit easily into all its standard activities. Bourdieu (1983a: 341) also emphasizes the relation between such knowledge and skills and the success with which artists operate in a specific art field:

'in an artistic field which has reached an advanced stage of this history, there is no place for naifs; more precisely, the history is immanent to the functioning of the field, and to meet the objective demands it implies (...) one has to possess the whole history of the field. Here it would be appropriate to point to the ideal-typical opposition between Rousseau and Duchamp. Rousseau, the painter as object, who does something other than what he thinks he is doing, because he knows nothing of the field he stumbles into, of which he is the plaything (...) By contrast, Duchamp, born into a family of painters, (...) has all the tricks of the artist's trade at his fingertips, i.e. an art of painting which (subsequently) implies not only the art of producing a work but the art of self-presentation.'

In Bourdieu's view, the question of whether artists possess the prerequisites for successful functioning in 
(a specific position within) a given artistic field is also closely associated with their social origins. He argues that those origins determine to a large degree their 'habitus' ${ }^{15}$, while the latter in turn steers them in the direction of a certain position. At the same time, the habitus determines largely whether artists are able to achieve and maintain a specific position. Bourdieu (1983a) argues that cultural analysis has to examine the relation between the positions a cultural field objectively has to offer at a given stage and the dispositions of the actors involved. Depending on the distribution of power at a certain moment, a field will have specific objective career opportunities. Actors in that field appraise and make use of those opportunities in accordance with their habitus. What is more, a successful career will only be reserved for those who reach the 'right' place, in other words, who take a position that accords with the dispositions they have acquired through upbringing and education. Thus, according to Bourdieu, artists who possess a considerable amount of economic and social capital are more inclined to choose for and maintain themselves in an avant-garde position in a particular field than others. The reason for this is that possession of economic capital frees them from the necessity 'to work for money,' but also that certain characteristics are more highly developed in artists with money and social relations than in others (Bourdieu 1983a: 349):

'self-assurance, audacity, indifference to profit - dispositions which, together with the flair associated with possession of a large social capital and the corresponding familiarity with the field, i.e. the art of sensing the new hierarchies and the new structures of the chances of profit, points towards the outposts, the most exposed positions of the avant-garde and towards the riskiest investments, which are also, however, very often the most profitable symbolically, and in the long run, at least for the earliest investors. ${ }^{16}$

Pursuing Bourdieu's insights, a series of studies have been conducted of the French literary field, which have also highlighted the influence of the social background and dispositions of writers on their career paths ('trajectories'). ${ }^{17}$ This research into the complex relations between the social origin, mental characteristics and the careers of writers has yielded interesting observations and suggestions. Subject to debate, however, is their reference to specific dispositions of writers to explain the positions they assumed or their success. The broad description usually given to these dispositions makes it hard to determine decisively whether an author possessed them or not. The attribution of specific dispositions to writers seems in many cases no more than an interpretation after the fact. Thus the conclusion that certain authors had dispositions such as 'a sense of investment' or 'indifference to profit' is only based on the fact of their successful literary career or their choice of an economically risky vocation as avantgarde writer.

Besides pioneering in the study of artistic creativity, the work of Getzels and Csikszentmihalyi (1976) overcomes one of the central difficulties in most research on artists' careers by going beyond post factum study. Instead of confining themselves to acknowledged artists, they looked at subjects who were in the process of becoming artists (art school students) and investigated how their careers developed in the course of time. They find that talent alone by no means accounted for their subjects' success. Their longitudinal study confirms the crucial importance of family background and certain personality features

\footnotetext{
${ }^{15}$ And his 'dispositions', which arise from and form part of this habitus. In his work, Bourdieu does not clearly distinguish between habitus and disposition, but uses them as more or less interchangeable concepts. Bourdieu considers the habitus to be an system of classification operating unconsciously in individuals, in other words a system of schemes of observation and evaluation that is applied to a broad range of areas and situations and thus brings the countless actions of individuals into agreement with one another.

${ }^{16}$ For Bourdieu an ideal typical example of an artist who discovered his 'natural place' too late is the nineteenth-century French writer Léon Cladel. Coming from the provincial petty bourgeoisie he did not possess the required disposition for the position he set his sights on (the Parisian Parnassus movement). This is said to have led him after years of disappointment and frustration to return in more than one sense to his origins and thereafter devote himself to writing regional novels 'in which rehabilitation gives way to self-indulgent depiction of peasant savagery (Ibid.: 349-351).'
}

${ }^{17}$ Cf., among others, Ponton (1977); Charle (1981); Viala (1985); Boschetti (1985); Gamboni (1989); Peru (1991); and Pinto (1991). See also Bourdieu's own studies (1992 and 1993) of the literary careers of Flaubert, Baudelaire, and their contemporaries. 
- such as the ability to attract attention from teachers and peers and flexibility in responding to demands in the career development of artists.

\section{Concluding comments}

Over the past thirty years, the study of careers in literature and the arts has developed into a flourishing and diverse field of research, which has addressed all kinds of questions that surround arts work from a variety of disciplinary and theoretical angles. Nonetheless, there are still areas that have been largely neglected up to now, while many other issues require further analysis.

One issue that, in my view, deserves closer attention is the role of the habitus (or dispositions) in the recruitment and career development of artists. Various authors have argued that this key concept in the work of Bourdieu and others is neither theoretically nor empirically sufficiently underpinned (see, for example, DiMaggio 1979; Gartman 1991). They point out that the habitus is assumed to be formed in a person's parental milieu and to involve a long-lasting relationship between people and their environment, but at the same time is said to be subject to change as a result of accumulated experiences. The question of how these two characteristics are related is, however, insufficiently elaborated. The same applies to the contention that differences in peoples' habitus are directly related to differences in their socioeconomic living conditions. Closer research on the nature, development and working of peoples' habitus or dispositions has not been conducted. For the time being we lack a reliable instrument for determining the extent to which writers and other artists have certain dispositions ${ }^{18}$ and how these are related to their social origins on the one hand, and their career paths on the other. At present, therefore, simply the question itself of the interconnection of social background and the choice and subsequent course of a particular (artistic) career calls for further investigation.

More or less a blind spot in the study of production and profession in the arts, already mentioned in the introduction to this chapter, is the 'para-artistic' or 'arts-related' occupations and the careers of their practitioners, such as publishers, reviewers, dealers, agents, impresarios, and curators. Only the occupation of journalist has received a lot of attention, from mass communication researchers and sociologists of work in particular (Tunstall 1971; Shoemaker and Reese 1996: chapter 5), but art journalists and reviewers have been largely neglected in such studies. Most research on other arts-related occupations (publishers, editors, dealers, etc.) has either highlighted their role as facilitators for or mediators of artistic work, or has focused on organizational aspects of individual firms (publishing houses, galleries, etc.), or entire sectors (the publishing industry, the art market, etc.). ${ }^{19}$ Our knowledge about the working conditions and characteristics of the occupational groups involved is mainly of an (auto)biographical and often anecdotal nature. Systematic comparisons of the 'job' of artist with 'artsrelated' occupations, and of the characteristics and career paths of the individuals who engage in one or the other line of work, could shed further light on the critical features of the whole gamut of occupations in the arts and on those of their practitioners. Moreover, as many case studies hint at a close relationship

\footnotetext{
${ }^{18}$ In this regard it can be remarked that experimental research such as has been carried out by psychologists, for example, on the question of whether and to what degree the personality characteristics of artists differ from those of non-artists has produced rather contradictory results. While some maintain that "no differentiation of the artist as a distinct personality type has been found in evidence offered by psychological tests, which shows that artists are not temperamentally unlike other persons and that they differ among themselves more than they differ from unselected groups' (B.T. Eidusun, quoted in Zolberg 1990: 122), other researchers conclude on the basis of a comparison of students of art academies with students in other programs that 'young artists, compared to college students of their age and sex, are socially reserved, introspective, alienated, imaginative, radical and self-sufficient' (Getzels and Csikszentmihalyi 1976).

${ }^{19}$ Of course, there are exceptions. The comprehensive study of the contemporary publishing industry by Coser et al. (1982) includes substantial chapters on 'the people who make books' and 'key-outsiders in the booktrade.' DiMaggio (1987b) details the backgrounds, schooling, career experiences, attitudes, and opinions of managers of the arts in the United States.
} 
between artists' careers and those of their critic-advocates, publishers, editors, or dealers, a more systematic account of such 'coupled' careers could provide us with a better understanding of the professional fortunes of the people involved and of the parameters of success or failure in the arts.

But what is probably needed most are more advanced, comparative research models that combine the various lines of research developed up to now, and that overcome the theoretical and methodological shortcomings of many existing studies.

\section{Longitudinal, comprehensive studies}

A major problem in the study of artistic careers is the lack of both longitudinal studies and comprehensive research models that take account of the various sets of variables affecting career development. Little, if any, true longitudinal research has been done charting the progress of a sample of writers or other artists over time. Most studies are cross-sectional; they use experimental, survey or census findings from a particular moment in time. Hence, they fail to grasp how, for example, writing and reading 'careers' develop in the course of people's lifetime, what forces and influences account for different career paths, and how such forces and influences are interrelated and reinforce one another. Biographies and casestudies of individual writers and other artists, of course, offer some insight into the development of artistic careers, but these are first of all written about a handful of eminent figures, and secondly, they are not systematic in their treatment. A number of studies have investigated the vicissitudes of a sample of artists over a longer period of time, but in most cases they have focused on the workings of one particular set of variables. Some studies, for example, have focused on the recognition of artists' work by critics and other experts or on their involvement in networks over time (Van Rees and Vermunt 1996), but they have provided little information as to how personality features or family values and other background variables affect the careers and reputations of those involved. Other researchers have considered the part of personality traits and/or social background characteristics in the career development of artists (Getzels and Csikszentmihalyi 1976; Top 1993), while paying little or no attention to institutional processes and mechanisms. At this stage, it seems that the study of artistic careers can only progress by integrating the various relevant clusters of variables into more sophisticated research designs, i.e. models of a multivariate and longitudinal nature.

\section{Comparative analysis}

Most research into arts work and artistic careers has focused on particular cultural domains - such as the field of literature or that of painting - in a particular period or country. Although in many studies reference is made to other cultural realms, times, or countries, their findings could be further specified and enriched by systematically considering the conditions and processes of production in one domain, country, or period in relation with those in others. The previous sections suggest that artistic work and careers should be viewed in connection with the support structures that enable artists to do their job, structures which are in turn contingent on larger social constituencies and thus vary over time and in place. They also indicate that a systematic comparison of arts work with other occupations can shed new light on critical features that might otherwise escape analysis. The same holds for systematic comparisons across culture producing domains. Crane (1976), for example, suggests that the elements of reward systems motivating and enabling specialists to be innovative are highly comparable in the realms of arts, science, and religion, and she identifies four distinct reward systems that have been found historically in each. Her observation that the same range of innovation processes can be found in all realms of culture does not mean that innovations in science, the arts, and religion are similar in form, content, or intention. Rather, it means that the differences, to a large extent, can be explained by the conditions of production in these realms. For example, as Peterson (1976) notes, contemporary American religious groups must compete for 'consumers' in a free competitive market, and their assertions about the world are subject to the test of science. On the other hand, knowledge in physics today is largely controlled by a selfperpetuating elite of esoteric specialists. These differences, however, are not inherent in the nature of the 
subject matter of these two realms as can be seen by reference to earlier times when the production systems of science and religion were very nearly just the opposite in Europe. Such observations suggest how fruitful it could be to make more systematic comparisons across culture producing domains. Another major challenge to future research, therefore, would be to develop a general scheme for making such comparisons, as this is currently lacking.

\section{Combining interpersonal, institutional, and societal levels of analysis}

In the past decades, the production of literature and other cultural artifacts has been studied at the level of personal (inter)action, relations among institutions and organizations, and the working of entire societies. As the theoretical perspectives and research methods employed at the various levels are often quite different, research at each level tends to develop more or less separately. Thus, while ideally work at, for example, the level of personal interaction complements work at the institutional or societal level, and while this may happen in the best individual studies, researchers working at different levels do not learn all they might from one another. Disciplinary boundaries also tend to hamper a fruitful exchange of ideas and results among scholars who share a common interest in the conditions and processes of cultural production. ${ }^{20}$

Research that takes explicitly into account societal level conditions has the advantage that it may enhance our understanding of how culture producing systems express and reinforce the sociopolitical system of the larger society and the attendant systems of domination and subordination, including social class, ethnicity, religion, and gender. On the other hand, such investigations are often so broad that they reduce explanation to mere postulates about macrostructural phenomena. Another danger in looking primarily from a macro perspective is that the workings of cultural (literary) production processes and the trajectories of the individuals involved may be seen to follow automatically from the societal level constraints (Peterson 1994; Bourdieu 1992). Such a 'mirror' or 'reflection' view ignores the institutional factors involved in the production of literature and other artistic expressions, and in the actual processes through which art and literature are constructed. Research conducted at the middle-range level of institutional analysis suggests that culture producing systems and organizations operate within and maintain their own boundaries, however permeable, and have some degree of autonomy. They have their own sets of norms, conventions, ideologies, and practices as well as an internal power structure which to a large extent guide artistic work and determine the careers of the individuals involved (Schmidt 1980; Bourdieu 1992). The strength of micro-analytical studies is that by more of less bracketing the societal and institutional levels of analysis, they have been able to detail how the norms and conventions of aesthetic judgment and collaboration allow artists of all types to create and to build careers in the process. In effect, these studies shed light on the culture of production rather than illuminating the production of culture (Fine 1992). In some cases, however, they can be criticized for unreflexively assuming the perspective of the group or occupational category under study. This 'going native' as it were, may yield incomplete and misleading readings of the field concerned (Clignet 1985; Bourdieu and Wacquant 1992). Moreover, research at the micro-analytical level, however rich in texture, is often so narrowly focused that it verges on the anecdotal and results in decontextualized cases which are of transitory interest and teach us little about the historical and structural conditions of arts work (Zolberg 1990).

Hence, a final challenge to future research would be to reconcile approaches at the micro, institutional, and societal level and thus to overcome the particular weaknesses of work at each level of analysis. Although at the theoretical level, such connections have been established (Bourdieu 1992) empirical studies substantiating them are still very rare.

\footnotetext{
20 The same problems are present in the field of literary reception studies (Andringa 1998), which presents a wide gap between detailed, qualitative studies on early literary socialization, on the one hand, and large-scale quantitative research into changing reading patterns, on the other. A similar gap exists between the experimental research into reading processes carried out by psychologists and the cultural participation surveys conducted by social scientists.
} 


\section{References}

Acci, J.d' 1987. “The case of Cagney and Lacey.” In Boxed in: Women and Television, H. Baehr and G. Dyer (eds.), 203-226. London: Pandora.

Albrecht, Milton C., James H. Barnett, and Mason Griff (eds.) 1970. The sociology of art and literature. A reader. London: Duckworth.

Alemann, Heinz von 1997. "Galerien als Gatekeeper des Kunstmarkts. Institutionelle Aspekte der Kunstvermittlung." In Soziologie der Kunst. Produzenten, Vermittler, Rezipienten, J. Gerhards (ed.), 211239. Opladen: Westdeutscher Verlag.

Altick, Richard D. 1962. "The sociology of authorship: The social origins, education and occupations of 1,100 British writers 1800-1935." The Bulletin of the New York Public Library 66:389-404.

Altick, Richard D. 1963. The English common reader. A social history of the mass reading public 1800-1900. Chicago: University of Chicago Press.

Andringa, Els 1998. "The empirical study of literature: Its development and future." In Janssen and Van Dijk, 1223.

Anheier, Helmut K. and Jürgen Gerhards. 1991. "Literary myths and social structure.” Social Forces 69:811-830.

Anheier, Helmut K. and Jürgen Gerhards. 1991b. "The acknowledgment of literary influence. A structural analysis of a German literary network." Sociological Forum 6:137-156.

Anheier, Helmut K., Jürgen Gerhards, and Frank P. Romo. 1995. "Forms of capital and social structure in cultural fields: Examining Bourdieu's social topography." American Journal of Sociology 100:859-903.

Barber, Bernard. 1963. "Some problems in the sociology of professions." Daedalus 92:669-688.

Becker, Howard S. 1982. Art Worlds. Berkeley, CA: University of California Press.

Berman, Russell A. 1983. "Writing for the book industry: The writer under organized capitalism." New German Critique 29:39-56.

Bernasco, Wim. 1994. Coupled careers. The effects of spouse's resources on success at work. Amsterdam: Thesis Publishers.

Berry, Ralph. 1970. "Patronage.” In The social context of art, J. Creedy (ed.). London: Tavistock.

Blau, Judith. 1988. "Study of the arts: A reappraisal." Annual Review of Sociology 14:269-292.

Bonham-Carter, Victor. 1978. Authors by profession. Volume I. London: The society of authors.

Boschetti, Anna. 1985. Sartre et Les Temps Modernes. Paris: Editions de Minuit.

Bourdieu, Pierre. 1980. "The production of belief: Contribution to an economy of symbolic goods [Extract from: La production de la croyance. Contribution à une économie des biens symboliques. Actes de la Recherche en Sciences Sociales 13, 1977: 3-43]." Media, Culture, and Society 2:261-293.

Bourdieu, Pierre. 1983. “Oekonomisches Kapital, kulturelles Kapital, soziales Kapital.” In Soziale Ungleichheiten (Soziale Welt, Sonderheft 2), R. Kreckel (ed.). Göttingen: Otto Schartz \& Co.

Bourdieu, Pierre. 1983a. "The field of cultural production, or: The economic world reversed." Poetics 12:311-356.

Bourdieu, Pierre. 1984. Distinction. A social critique of the judgement of taste [Translation of La distinction. Paris: Minuit, 1979]. London and New York: Routledge \& Kegan Paul.

Bourdieu, Pierre. 1985. "The market of symbolic goods [Translation of Le marché des biens symboliques. L'Année Sociologie 22, 1971, 49-126]." Poetics 14:13-44.

Bourdieu, Pierre. 1992. Les règles de l'art. Paris: Seuil.

Bourdieu, Pierre. 1993. The field of cultural production. Essays on art and literature. Cambridge, MA: Polity Press.

Bourdieu, Pierre and Alain Darbel. 1969. L'amour de l'art. Les musées d'art européens et leur public. Paris: Minuit.

Bourdieu, Pierre, Kees van Rees, Siegfried J. Schmidt and Hugo Verdaasdonk, 1989. "The structure of the literary field and the homogeneity of cultural choices. Panel discussion." In: Ibsch et al., 437-443.

Bourdieu, Pierre and Loïc D.J. Wacquant. 1992. An invitation to reflexive sociology. Chicago: University of Chicago Press.

Boxman, Edward A.W. 1992. Contacten en carrière. Een empirisch-theoretisch onderzoek naar de relatie tussen sociale netwerken en arbeidsmarktpositie [Contacts and careers. An empirical-theoretical investigation of the relationship between social networks and labor market position]. Amsterdam: Thesis Publishers.

Boyer, Paul S. 1968. Purity in print: The vice-society movement and book censorship in America. New York: Scribner.

Bradbury, Malcom. 1971. The social context of modern English literature. Oxford: Blackwell.

Braden, Su. 1978. Artists and people. London: Routledge \& Kegan Paul.

Brasey, Edouard. 1987. L'effet Pivot. Paris: Ramsay.

Breed, Walter. 1955. Social control in the newsroom: A functional analysis, vol. 33.

Bystryn, Marcia. 1978. "Art galleries as gatekeepers. The case of the abstract expressionists." Social Research 45:390-408.

Cantor, Muriel G. and Joel Cantor. 1991. Prime time television: Content and control. Beverley Hills, CA: Sage Publications.

Charle, Christophe. 1981. "Situation du champ littéraire.” Littérature 44:8-20. 
Child, John and Janet Fulk. 1982. "Maintenance of occupational control: The case of professionals." Work and Occupations 9:155-192.

Clignet, Rémi. 1985. The structure of artistic revolutions. Philadelphia: University of Pennsylvania Press.

Clor, Harry M. 1969. Obscenity and public morality: Censorship in a liberal society. Chicago: University of Chicago Press.

Coser, Lewis A., Charles Kadushin, and Walter W. Powell. 1982. Books. The culture and commerce of publishing. New York: Basic Books.

Crane, Diana. 1976. "Reward systems in art, science, and religion.” American Behavioral Scientist 19:719-734.

Crane, Diana. 1987. The transformation of the avant-garde: The New York art world 1940-1985. Chicago: University of Chicago Press.

Crane, Diana. 1989. "Reward systems in avant-garde art: Social networks and stylistic change." In Art and society. Readings in the sociology of the arts, A. W. Foster and J. R. Blau (eds.), 261-272. Albany NY: State University of New York Press.

Davis, Kenneth C. 1984. Two-bit culture: The paperbacking of America. Boston, MA: Houghton Mifflin.

Dijk, Nel van. 1994. De politiek van de literatuurkritiek. De reputatie-opbouw van Menno ter Braak in de Nederlandse letteren [Pragmatic considerations in literary criticism. The establishment of the reputation of Menno ter Braak in Dutch literature]. Delft: Eburon.

Dijk, Nel van. 1999. "Top nor literary fringe. Careers and reputation of middle group authors. In Griswold et al., 405-422.

DiMaggio, Paul. 1982. "Cultural entrepeneurship in nineteenth-century Boston: The organization of an institutional base for high culture in America." Media, Culture, and Society 4:33-50.

DiMaggio, Paul, 1979. “On Pierre Bourdieu. Review essay.” American Journal of Sociology 84:1466-1474.

DiMaggio, Paul. 1987a. "Classification in art." American Sociological Review 52:440-455.

DiMaggio, Paul, 1987b. Managers of the arts. Careers and opinions of senior administrators of U.S. art museums, symphony orchestras, resident theaters, and local arts agencies. Washington, DC and Cabin John, Maryland: Seven Locks Press.

DiMaggio, Paul and Michael Useem. 1978. "Cultural property and public policy: Emerging tensions in government support for the arts.” Social Research 45:357-389.

Dörner, Andreas and Ludgera Vogt. 1994. Literatursoziologie. Literatur, Gesellschaft, politische Kultur. Opladen: Westdeutscher Verlag.

Douglas, Mary and Baron Isherwood. 1979. The world of goods: Toward an anthropology of consumption. New York: Basic Books.

Dubin, Steven C. 1992. Arresting images: Impolitical art and Uncivil Actions. New York: Routledge.

Dubin, Steven C. 1987. Bureaucratizing the muse: Public funds and the cultural worker. Chicago: University of Chicago Press.

Faulkner, Robert R. 1983. Music on demand. New Brunswick: Transaction.

Fine, Gary Alan. 1992. "The culture of production: Aesthetic choices and constraints in culinary work." American Journal of Sociology 97:1268-1294

Finnish Arts Council. 1988-1996. The Finnish Arts Council project on the status of artists 1985-1996. Helsinki: Finnish Arts Council.

Flap, Henk .D. and Frits Tazelaar. 1988. "De rol van informele sociale netwerken op de arbeidsmarkt: Flexibilisering en uitsluiting [The role of informal social networks in the labor market: Flexibilization and exclusion].” In De flexibele arbeidsmarkt. Theorie en praktijk [The flexible labor market. Theory and practice], H. D. Flap and A. A. Arts (eds.). Deventer: Van Loghum Slaterus.

Fohrbeck, Karla and Andreas J. Wiesand. 1972. Der Autoren-report. Reinbek: Rowohlt Verlag.

Fohrbeck, Karla and Andreas J. Wiesand. 1975. Künstler-Report. Munich: Carl Hanser Verlag.

Foster, Arnold W. and Judith R. Blau. 1989. Art and society. Readings in the sociology of the arts. Albany NY: State University of New York Press.

Gamboni, Dario. 1989. La plume et le pinceau. Odile Redon et la littérature. Paris: Editions de Minuit.

Gedin, Per. 1977. Literature in the marketplace. Translated by George Bisset. London: Faber.

Getzels, Jacob W. and Mihaly Csikszentmihalyi. 1976. The creative vision: A longitudinal study of problem finding in art. New York: John Wiley.

Gilmore, Samual. 1990. "Art worlds: Developing the interactionist approach to social organization.” In Symbolic interaction and cultural studies, H. S. Becker and M. M. McCall (eds.), 148-178. Chicago: University of Chicago Press.

Gitlin, Todd. 1983. Inside prime time. New York: Pantheon.

Goode, William J. 1960. "Encroachment, charlatanism, and the emerging professions: Psychology, sociology, and medicine." American Sociological Review 25:902-914.

Gartman, David, 1991. "Bourdieu's distinction.” American Journal of Sociology 97:421-447.

Granovetter, Mark. 1995 [1974]. Getting a job. A study of contacts and careers. Chicago: University of Chicago Press.

Greenfeld, Liah. 1988. "Professional ideology and patterns of 'gatekeeping'. Evaluation and judgment within two 
art worlds." Social forces 66:903-925.

Greenfeld, Liah. 1989. Different worlds. A sociological study of taste, choice and success in art. Cambridge, MA: Cambridge University Press.

Greenwood, Ernest. 1966. “The elements of professionalization.” In Professionalization, H. M. Vollmer and D. L. Mills (ed.). Englewood Cliffs, NJ: Prentice Hall.

Greer, Germaine. 1979. The obstacle race: the fortunes of women painters and their work. London: Secker \& Warburg.

Griff, Mason. 1970. "The recruitment and socialization of artists." In Albrecht et al., 145-158

Griffin, Dustin. 1996. Literary patronage in England 1650-1800. Cambridge: Cambridge University Press.

Griswold, Wendy. 1981. “American character and the American novel.” American Journal of Sociology: 740-765.

Griswold, Wendy. 1987. "The fabrication of meaning: literary interpretation in the United States, Great Britain, and the West Indies.” American Journal of Sociology 92:1077-1117.

Griswold, Wendy. 1992. "The writing on the mud wall: Nigerian novels and the imaginary village.” American Sociological Review 57:709-724.

Griswold, Wendy, Susanne Janssen and Kees van Rees (eds.). 1999. Conditions of cultural production and reception. Special issue of Poetics 26 (5/6).

Gross, John. 1991 [1969]. The rise and fall of the man of letters. English literary life since 1800. With a new introduction and afterword. Harmondsworth: Penguin Books.

Hall, Richard A. 1994. Sociology of work. Perspectives, analyses, and issues. Thousand Oaks: Pine Forge Press.

Heilbron, Johan. 1992. Kunst leren [Learning art]. Rijswijk: Ministerie van Welzijn, Volksgezondheid en Cultuur.

Heilbrun, James and Charles M. Gray. 1993. The economics of art and culture. An American perspective. Cambridge, MA: Cambridge University Press.

Hirsch, Paul M. 1977. “Occupational, organizational, and institutional models in mass communication.” In Strategies for communication research, P. M. Hirsch et al. (eds.), 13-42. Beverly Hills, CA and London: Sage Publications.

Ibsch, Elrud, Dick Schram and Gerard Steen (eds.). 1989. Empirical studies of literature. Amsterdam and Atlanta: Rodopi.

Janssen, Susanne. 1994. In het licht van de kritiek. Variaties en patronen in de aandacht van de literatuurkritiek voor auteurs en hun werken [In the light of criticism: Divergences and patterns in the attention of literary criticism for authors and their works]. Hilversum: Verloren.

Janssen, Susanne. 1997. 'Reviewing as social practice: Institutional constraints on critics' attention for contemporary fiction." Poetics 24:275-298.

Janssen, Susanne. 1998. "Side-roads to success: The effect of sideline activities on the status of writers." Poetics 25:265-280.

Janssen, Susanne and Nel van Dijk (eds.). 1998. The empirical study of literature and the media. Current approaches and perspectives. Rotterdam: Barjesteh and Co's.

Jeffri, J. 1988. Information on artists. New York: Columbia University / Research Center for Arts and Culture.

Kadushin, Charles K. 1976. "Networks and circles in the production of culture." American Behavioral Scientists 19:769-785.

Kartunen, Sari. 1998. "How to identify artists? Defining the population for 'status-of-the-artist' studies." Poetics 26:1-19.

Laurenson, Diana. 1972. "The writer and society.” In The sociology of literature, D. Laurenson and A. Swingewood, 91-166. London: MacGibbon \& Kee.

Lenman, Robin. 1997. Artists and society in Germany 1850-1914. Manchester and New York: Manchester University Press.

Levy, Emanuel. 1989. "The choice of acting as a profession.” In Foster and Blau, 111-131.

Lowenthal, Leo. 1961. Literature, popular culture, and society. Englewood Cliffs, NJ: Prentice Hall.

Lowenthal, Leo. 1964. “The reception of Dostojevski's work in Germany: 1880-1920." In The arts in society, R. Wilson (ed.), 124-147. Englewood Cliffs, NJ: Prentice-Hall.

Markert, John. 1984. Beyond gatekeepers: Romance publishing and the production of culture. Nashville, TN: Vanderbilt University.

McQuail, Denis. 1994. Mass communication theory. An introduction. Third edition. London: Sage Publications.

Mennell, Stephen. 1976. "Cultural policy in towns: A report on the Council of Europe's experimental study of cultural development in European towns." Council of Europe, Strasbourg.

Meyer, Leonard. 1967. Music, the arts and ideas. Chicago: University of Chicago Press.

Minihan, Janet. 1977. The nationalization of culture: The development of state subsidies to the arts in Great Britain. London: Hamish Hamilton.

Moulin, Raymonde. 1987. The French art market. A sociological view [Abridged edition of Le marché de la peinture en France. Paris: Minuit, 1967]. New Brunswick and London: Rutgers University Press.

Moulin, Raymonde et al. 1985. Les artistes. Essai de morphologie sociale. Paris: La documentation francaise. Nash, Dennison J. 1989. "The socialization of an artist: The American composer." In Foster and Blau, 85-96. National Endowment for the Arts. 1982/1992. A sourcebook of art statistics. Washington, DC: NEA. 
Nies, Fritz (ed.). 1996. “Literaturimport und Literaturkritik: das Beispiel Frankreich.” . Tübingen: Gunter Narr Verlag.

Nochlin, Linda. 1973. "Why have there been no great women artists?” In Art and sexual politics, T. B. Hess et al. (eds.) London: Collier-Macmillan.

Oosterbaan Martinius, Warna. 1990. Schoonheid, welzijn, kwaliteit. Kunstbeleid en verantwoording na 1945 [Beauty, welfare, quality. Art policy and its legitimization after 1945. The Hague: Gary Schwartz / SDU.

Parkhurst Clark, Priscilla. 1987. Literary France. The making of a culture. Berkely, CA: University of California Press.

Pearson, Nicolas M. 1980. The state and the visual arts: State intervention in the visual arts since 1760. London: Macmillan.

Pelles, Geraldine. 1963. Art, artists and society. Origins of a modern dilemma. Painting in England and France 1750-1850. Englewoord Cliffs, NJ: Prentice-Hall.

Peru, J. 1991. "Une crise du champ littéraire francais. Le debat sur la 'littérature prolétarienne' (1925-1935)." Actes de la Recherche en Sciences Sociales 89:47-65.

Peterson, Richard. A. 1976. "The production of culture. A prolegomenon.” American Behavioral Scientist: 19:669-684.

Peterson, Richard A. 1994. "Cultural studies through the production perspective: Progress and prospects." In The sociology of culture. Emerging theoretical perspectives, D. Crane (ed.), 163-189. Cambridge, MA: Basil Blackwell.

Peterson, Richard A. and Howard G. White. 1989. "The simplex located in art worlds.” In Foster and Blau, 243259.

Pevsner, Nikolaus. 1970. "French and Dutch artists in the seventeenth century." In Albrecht et al., 363-369.

Pinto, Louis. 1991. "Tel Quel: Au sujet des intellectuels de parodie." Actes de la Recherche en Sciences Sociales 89:66-77.

Ponton, Rémy. 1977. Le champ littéraire de 1865 à 1905. Paris: EHESS.

Powell, Walter W. 1985. Getting into print. The decision-making process in scholarly publishing. Chicago: University of Chicago Press.

Rarisch, Ilse. 1976. Industrialisierung und Literatur: Buchproduktion, Verlagswesen und Buchhandel in Deutschland im 19. Jahrhundert in ihrem statistischen Zusammenhang. Berlin: Colloquium Verlag.

Rees, C.J. van. 1983. "Advances in the empirical sociology of literature and the arts.” Poetics 12:285-310.

Rees, C.J. van, 1983a. "How a literary work becomes a masterpiece: On the threefold selection practised by literary criticism. Poetics 12:397-418.

Rees, C.J. van. 1985. "Editorial. Empirical sociology of cultural productions.” Poetics 14:5-11.

Rees, C.J. van. 1987. "How reviewers reach consensus on the value of literary works." Poetics 16:275-294.

Rees, Kees van and Jeroen Vermunt. 1996. "Event history analysis of authors' reputation: Effects of critics' attention on debutants' careers." Poetics 23:317-333.

Ridgeway, Sally. 1989. “Artist groups: Patrons and gatekeepers.” In Foster and Blau, 205-220.

Rodden, John. 1989. The politics of literary reputation. The making and claiming of 'St. George' Orwell. New York: Oxford University Press.

Rollin, Roger B. 1976. “Trash gratia artis: Popular culture as literature.” Intellect 105:191-194.

Rosenblum, Barbara. 1978. Photographers at work: A sociology of photographic styles. New York: Holms \& Meier.

Rosengren, Karl E. 1983. The climate of literature. Sweden's literary frame of reference 1953-1976. Lund: Studentlitteratur.

Rosengren, Karl E. 1985. "Time and literary fame.” Poetics 14:157-172.

Rosengren, Karl E. 1987. "Literary criticism: Future invented.” Poetics 16:295-326.

Rusch, Gebhard. 1999. "The status of authors within literary systems: Challenging the canon. An explorative investigation of Alfred Döblin's status within the German literary system in 1997." In Griswold et al., 367384.

Ryan, John and Richard A. Peterson. 1982. "The product image: The fate of creativity in country music writing." Annual reviews of communication research 10:11-32.

Schmidt, Siegried J. 1980 and 1982. Grundriss der Empirischen Literaturwissenschaft. Frankfurt/M: Suhrkamp.

Schmidt, Siegfried J. 1993. Literaturwissenschaft und Systemtheorie. Positionen, Kontroversen, Perspektiven. Opladen: Westdeutscher Verlag.

Schmidt, Siegfried J. 1998. "How to balance open accounts? Some requirements for a further development of the empirical study of literature." In Janssen and Van Dijk, 92-108.

Shoemaker, Pamela J. and Stephen D. Reese. 1996 [1991]. Mediating the message: Theories of influences on mass media content. White Plains, N.Y.: Longman.

Simpson, Charles. 1981. Soho: The artist in the city. Chicago: University of Chicago Press.

Speier, Hans. 1977. "The communication of hidden meaning." Social research 44:471-501.

Stolwijk, Chris. 1998. Uit de schilderswereld. Nederlandse kunstschilders in de tweede helft van de negentiende eeuw [From the world of painters. Dutch painters in the second half of the nineteenth century]. Leiden: 
Primavera Press.

Strauss, Anselm. 1970. "The art school and its students: A study and an interpretation.” In Albrecht et al., 159-177. Sutherland, David Earl. 1989. "Ballet as a career.” In Foster and Blau, 97-110.

Sutherland, John A. 1976. Victorian novelists and publishers. Chicago: University of Chicago Press.

Sutherland, John A. 1978. Fiction and the fiction industry. London: Athlone Press.

Swayze, Harold. 1962. Political control of literature in the USSR 1946-1959. Cambridge, MA: Harvard University Press.

Tas, Jaap van der. 1990. Kunst als beroep en roeping [Art as profession and vocation]. Zeist: Kerkebosch.

Tebbel, John. 1975. A history of book publishing in the United States. Vol. 2: The expansion of an industry, 18651919. New York: Bowker.

Tebbel, John. 1978. A history of book publishing in the United States. Vol 3: The golden age between the two wars, 1920-1940. New York: Bowker.

Thomas, D. 1969. A long time burning. London: Routledge and Kegan Paul.

Throsby, David. 1986. Occupational and employment characteristics of artists. Sidney: Australia Council.

Throsby, David. 1992. “Artists as workers.” In Cultural economics, R. Towse and A. Kakee (eds.), 201-208. Heidelberg: Springer Verlag.

Throsby, David. 1994. "The production and consumption of the arts: A view of cultural economics.” Journal of Economic Literature 32:1-29.

Throsby, David. 1996. "Disaggregated earning functions for artists.” Pp. 331-346 in Economics of the arts: selected essays, edited by V. A. Ginsburgh and P. M. Menger. Amsterdam: North Holland.

Throsby, David and D. Mills. 1989. When are you getting a real job? An economic study of artists in Australia. Sidney: Australia Council.

Throsby, David and B. Thompson. 1994. But what do you do for a living? Sidney: Australia council.

Thurston, Carol. 1987. The romantic revolution: Romantic novels for women and the quest for a new sexual identity. Urbana: University of Illinois Press.

Top, Titia. 1993. Art and gender. Creative achievement in the visual arts. Groningen: University of Groningen.

Towse, Ruth. 1992. The economic and social characteristics of artists in Wales. Cardiff: Welsh Arts Council.

Towse, Ruth. 1996. The economics of artists' labor markets. ACE Research report 3. London: The Arts Council of England.

Tuchman, Gaye. 1978. Making news. New York: Free Press.

Tuchman, Gaye. 1975. "Women and the creation of culture." In Another voice: Feminist perspectives on social life and social science, edited by M. Millman and R. M. Kanter (eds.). New York: Anchor.

Tuchman, Gaye. 1989. Edging women out: Victorian novelists, publishers, and social change. New Haven: Yale University Press.

Tunstall, Jeremy. 1971. Journalists at work. Specialist correspondents: their news organizations, news sources, and competitor-colleagues. London: Constable.

Useem, Michael. 1976. "Government patronage of science and art in America." American Behavioral Scientist 19:785-804.

Verdaasdonk, Dorothee, 1994. Marginality a characteristic of artistic product, the need of personal networks to sustain an artistic career.' In Institution and innovation. Avant Garde Critical Studies, K. Beekman (ed.), 37-54. Amsterdam: Rodopi.

Verdaasdonk, Hugo, 1985. Empirical sociology of literature as a non-textually oriented form of research. Poetics 14: $173-186$.

Viala, Alain. 1985. Naissance de l'écrivain. Sociologie de la littérature a l'âge classique. Paris: Les Editions de Minuit.

Voorst, Sandra van der. 1997. Weten wat er in de wereld te koop is: Vier Nederlandse uitgeverijen en hun vertaalde fondsen 1945-1970. The Hague: SDU Uitgevers.

Wassall, Gregory H. and Neil O. Alper. 1992. "Towards a unified theory of the determinants of the earnings of artists.” In Cultural economics, R. Towse and A. Khakee (eds.), 187-200. Berlin: Springer.

Watt, Ian. 1993 [1957]. The rise of the novel. London: The Hogarth Press.

White, David M. 1950. “The gatekeeper: A case-study in the selection of news.” Journalism Quarterly 27:383-390.

White, Harrison C. and Cynthia A. White. 1993 [1965]. Canvases and careers. Institutional change in the French painting world. New York: John Wiley.

Whiteside, Thomas. 1981. The blockbuster complex. Conglomerates, show business and book publishing. Middletown, Connecticut: Wesleyan University Press.

Wilensky, Harold L. 1964. “The professionalization of everyone?” American Journal of Sociology 70:137-158.

Williams, Raymond. 1980 [1961]. The long revolution. Harmondsworth: Penguin Books.

Wolfe, Tom. 1975. The painted word. New York: Bantam Books.

Zolberg, Vera. 1990. Constructing a sociology of the arts. Cambridge: Cambridge University Press. 